\title{
Monitoring Irrigation Water Pollution of Nile Delta of Egypt with Heavy Metals
}

\author{
Saad A.E Abdelrazek ${ }^{1}$
}

\begin{abstract}
The present work attempts to study the distribution of heavy metals in some drainage and canals located in Northern part of Egypt. Eight metals (Fe, Mn, Zn, Cu, Pb, $\mathrm{Cd}, \mathrm{Co}$ and $\mathrm{Ni}$ ) were determined in water. Metals concentrations in water varied between in different years and were, Fe (0.18 -117.11), Mn (0.01 -58.98), Zn (0.01 90.56 ), Cu (0.005 -65.70), Pb (0.016 -36.64), Cd (0.000 14.69), Co(0.002-89.72), Ni (0.019 -73.22$) \mathrm{mg} / \mathrm{l}$ respectively. Concentrations of heavy metals in water are compared with many guidelines to predict status of water pollution (Guideline for water irrigation agricultural FAO, 2017 and Specifications of fresh water, according to Law 48 of 1982 ,Article 60 of the Regulations). The results showed that all canals in this study are considered as sources of worst water for irrigation, and also all drains and mixed canals are considered above division of increasing salinity problems of irrigation water. Finally, the main drains are considered highly saline for irrigation and classified as salinity problems, So causing adverse impact on soil properties and productivity. The concentrations of heavy metals, pH and salinity are pollutants in all canals, and are still above the critical limits and could not be used for irrigation. This study recommends effective implementation of laws and regulations, removal of encroachments and buildings on the canal's borders and waterways, Nile River, raise awareness and Provide the necessary resources to separate the waste of human activity from the biological and non-biological systems (biotic and a biotic).
\end{abstract}

Keywords: Irrigation water pollution, Heavy metals, Legislative approaches in Egypt, North Egypt.

\section{INTRODUCTION}

Increase of waste production is correlated with economical and demographical development. Development also leads to negative effects on the environment and economy of many countries. intensification of the economic activities and demographical development in Egypt are accompanied by an increase in solid waste production

Water pollution is a major problem in the world and requires constant review and measurements at all levels (rivers, artesian wells) Water pollution is one of the

DOI: 10.21608 /asejaiqjsae.2019.50350

${ }^{1}$ Soil Salinity and Alkalinity Department, Alexandria Soil, Water and Environment Research Institute, Agriculture Research Center (ARC), Giza, Egypt

Email: Samad_saad@yahoo.com

Received August 6, 2019, Accepted September 26, 2019 most common causes of death globally (Fattah, and Abdelrazek ,2014). Some $90 \%$ of Egypt's villages suffer from some degree of water pollution, and nearly 50 million people lack access to safe drinking water. As developing countries suffer from increasing problems of pollution day after day, the major industrial countries face major problems that still have no solution and do not see any hope of overcoming pollution obstacles. (Abdel-Shafy, and Aly, 2012).

In the most recent national report on water quality in the USA, $45 \%$ of assessed stream, $47 \%$ of assessed lake, and $32 \%$ of assessed bay and estuarine are classified as polluted (Ali et al.,2013)

Water is typically referred to as polluted when it is impaired by anthropogenic contaminants and either does not support a human use, such as irrigation water (Soliman et al., 2006)

Some industrial facilities generate ordinary domestic sewage that can be treated by municipal facilities. There are contaminants such as pollution, oils, grease, or toxic contaminants such as heavy metals, volatile organic compounds or ammonia, which require specialized treatment systems (Hamed et al.,2013)

In Egypt, there are many resources of water, starting with Nile River, groundwater in Delta and Valley, deep groundwater, drainage water reuse such as canals in the Delta region, Bahr El-Baqar, Mahmodia canal, Damietta Branch, El Salam Canal, El-Gharbia Main, Abu-Qir , Rosetta Branch, , El-Umoum, El-Nasser Canal in Nubaria, Ismailia Canal.

Availability and current use of water of Nile River is 55.5, BCM/annum, (75.2\%), Underground availability 11.3 (Billion Cubic Meters) BCM/annum (15.3\%), Agriculture availability $5 \mathrm{BCM} /$ annum (6.8\%), Wastewater availability $1.5 \mathrm{BCM} /$ annum (2.03\%), Rainfall $0.5 \mathrm{BCM} /$ annum $(0.67 \%)$ with a total of 73.8 $\mathrm{BCM} /$ annum, the total current use is $62.6 \mathrm{BCM} / \mathrm{annum}$, (Allam, 2007).

Water pollution is a relative concept; where there is no water is completely pure (Abdelrazek and Shouman, 2016). Contaminated water that poses threat to human 
can be used in the field of industry. (Elsoury et al., 2015)

The primarily responsible for the pollution of waterways and soil with heavy metals is the increase in industrial activity, along with the residues from mineral fertilizers. A report was published in 1992 denoting that metallurgical industry is responsible for about $50 \%$ of industrial waste while spinning, weaving, dyeing responsible for disbursing about $30 \%$ of the total industrial sewage (Abdelrazek and Fayed, 2019). That about 250 industrial establishments in Greater Cairo, which represent about $35 \%$ of the total industrial activity, contribute to about $40 \%$ of the total loads of heavy metals dumped into waterways and this is equivalent to 0.72 tons per day or the equivalent of 273 tons of heavy metals in the year to the waterway. As in the Delta with about 150 manufacturing facility is responsible for the exchange of about $25 \%$ of the total loads of heavy metals in waterways - this quantity does not include the city of Alexandria, where there were about 175 industrial facilities (representing about $25 \%$ of the total industrial activity in Egypt - and responsible exchange for $10 \%$ of the total loads of heavy metals in waterways) (El Bouraie et al., 2010).

Main Sources of pollution: Agricultural runoffs, industrial effluents and municipal sewage are being recklessly dumped into the Nile River, gradually making its water unfit for human consumption. Sewage water from slums and many other areas in Cairo is discharged into the river untreated due to lack of water treatment plants (Darwish and Abdelrazek,2016) . Agricultural runoffs frequently contain pollutants from pesticides and herbicides, which have negative effects on the river and the people using it. Industrial effluents are often highly toxic, containing heavy metals that can combine with the suspended solids in domestic wastewater to form muck. All of these factors combine together to make Nile a polluted river which may spell doom for the generations to come (Abdelrazek, 2014).

The aim of the present study was to investigate the distribution of heavy metals in same drainage canal located in Northern Egypt. Eight metals (Fe, Mn, Zn, $\mathrm{Cu}, \mathrm{Pb}, \mathrm{Cd}, \mathrm{Co}, \mathrm{Ni}$ ) were determined in water and manage, protect the irrigation water quality

\section{MATERIALS AND METHODS}

\section{Study Area}

The data were also subjected to Pearson correlations analysis, and cluster analysis, to identify the relationship between the variables and to find out the key soil parameters that are sensitive to heavy metals exposure (Hafez, 2004)
Main Sources of pollution: Agricultural runoffs, industrial effluents and municipal sewage are being recklessly dumped into the Nile River, gradually making its water unfit for human consumption Drainage Research Institute ,2000). Sewage water from slums and many other areas in Cairo is discharged into the river untreated due to lack of water treatment plants. Agricultural runoffs frequently contain pollutants from pesticides and herbicides, which have negative effects on the river and the people using it (Ghallab ,2000). Industrial effluents are often highly toxic, containing heavy metals that can combine with the suspended solids in domestic wastewater to form muck. All of these factors combine together to make Nile a polluted river which may spell doom for the generations to come (Abdelrazek and Ragab Fayed ,2018).

\section{Sampling:}

Water: Sampling processes based on scientific methodology that will preserve as much as possible the chemical and physical properties of water. After cleaning the glass bottles, acid solution $(\mathrm{HCl})$ was used to wash the bottles, followed by tap water, then several times with distilled water. The Water way finally dried in an oven temperature at $60 \mathrm{C}^{\circ}$ (APHA, 1971). The Wastewater was collected from different drains canal sources in Egypt. Wastewater sample collected $1 \mathrm{~km}$ from the beginning of the drain, after $10 \mathrm{~km}$ from the beginning of the drain, and after $20 \mathrm{~km}$ from the beginning of the drain. Mean samples were taken within 12 months of each year and Location of the samples along the North Egypt Table (1).

\section{Analysis:}

Water: Sub sample of $500 \mathrm{ml}$ water were preserved with $2 \mathrm{ml}$ nitric acid to prevent precipitation and adhesion of metals on the bottle walls (APHA, 1971)

1) $\mathrm{pH}$ was measured using Beckman's $\mathrm{pH}$ meter (Jackson, 1958). Electrical conductivity was measured

2) (EC dS/m) using conductometer (Jackson, 1958).

3) The concentrations of total $\mathrm{Fe}, \mathrm{Mn}, \mathrm{Zn}, \mathrm{Cu}, \mathrm{Pb}, \mathrm{Cd}$, $\mathrm{Co}$ and $\mathrm{Ni}$ were determined using inductively coupled plasma atomic emission spectroscopy (ICPAES).

\section{Statistical analysis}

All obtained data of soil, plant and water were statistically analyzed using statistical software SYSTAT- 12. 


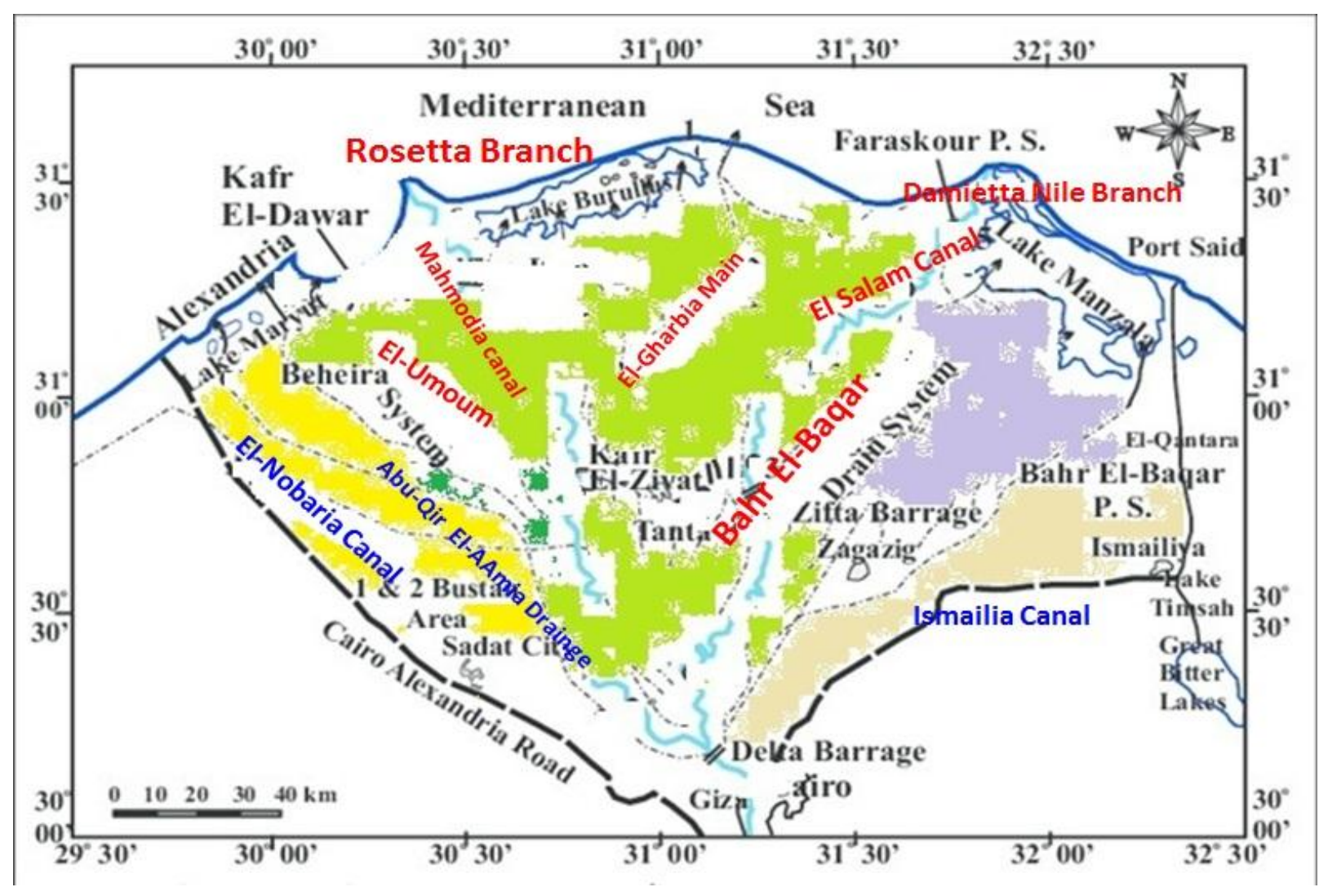

Fig.1. Geographical location of some selected canals in North Egypt

Table 1. Location of the samples along the North Egypt

\begin{tabular}{|c|c|c|c|}
\hline & Sites & Latitude & Longitude \\
\hline 1 & Bahr El-Baqar & $31^{\circ} 11^{\backslash} 51 \backslash \backslash$ & $32^{\circ} 15^{`} 10^{\prime \prime}$ \\
\hline 2 & Mahmodia canal & $31^{\circ} 12^{\backslash}$ & $30^{\circ} 53^{\backslash}$ \\
\hline 3 & Damietta Nile Branch & $31015 \backslash 23 \backslash \backslash$ & $31^{\circ} 48^{\backslash} 39^{\prime \prime}$ \\
\hline 4 & El Salam Canal & $32^{\circ} 40 \backslash 44 \backslash \backslash$ & $31^{\circ} 40 \backslash 16 \backslash \backslash$ \\
\hline 5 & El-Gharbia Main & $31006 \backslash 34 \backslash \backslash .60$ & $30^{\circ} 44 \backslash 55 \backslash \backslash$ \\
\hline 6 & Abu-Qir El-AAmia Drainge & $31^{\circ} .32 \backslash 25 \backslash \backslash$ & $30^{\circ} .07 \backslash 55 \backslash \backslash$ \\
\hline 7 & In Rosetta Branch & $30^{\circ} 11 \backslash 21 \backslash \backslash$ & $31^{\circ} 6134 \backslash 1$ \\
\hline 8 & El-Umoum & $31^{\circ} 10 \backslash 12 \backslash \backslash$ & $31^{\circ} 15 \backslash 23 \backslash \backslash$ \\
\hline 9 & Ismailia Canal & $30^{\circ} 36 \backslash 37 \backslash \backslash$ & $32^{\circ} 16 \backslash 20 \backslash \backslash$ \\
\hline 10 & El-Nobaria Canal & $30^{\circ} 31 \backslash 67 \backslash \backslash$ & $30^{\circ} 44 \backslash 32 \backslash$. \\
\hline
\end{tabular}

One-way analysis of variance was carried out to compare the means of different treatments and least significant differences at $\mathrm{P}<0.05$ were obtained using Duncan s multiple range test (DMRT) (Duncan, 1955).

\section{RESULTS AND DISCUSSION}

\section{Heavy metals in irrigation water}

\section{1-Bahr El-Baqar}

Bahr El-Baqar is located in the eastern part of the Nile Delta and runs for about $170 \mathrm{~km}$ from Cairo to Lake Manzala. Arable lands irrigated by water of this drain and its tributaries are about 317,000 ha. The main drain collects water from the two secondary drains of Bilbeis and Qalyubya, which collect water from the two drains, of Gabal El Asfar and Shebeen (DRI, 2005).

Egypt is one of the countries that lies in an arid and non-arid climate, which causes water shortage, which is one of the most serious problems in Egypt, affecting agricultural expansion and reclamation projects. Which drives Egypt to reuse agricultural, sanitary and industrial waste water in irrigation by mixing it with pure water from the Nile River. 
Table 2. Monitoring in the concentrations of heavy metals $\left(\mathrm{mgL}^{-1}\right)$ in irrigation water of selected drainage water North Egypt *

\begin{tabular}{|c|c|c|c|c|c|c|c|c|c|c|c|}
\hline \multirow[t]{2}{*}{ Drain canal } & \multirow[t]{2}{*}{ year } & \multirow[t]{2}{*}{ pH } & \multirow{2}{*}{$\begin{array}{r}\text { E.C } \\
d S / m\end{array}$} & $\mathbf{F e}$ & Mn & Zn & $\mathbf{C u}$ & $\mathbf{P b}$ & Cd & Co & $\mathbf{N i}$ \\
\hline & & & & \multicolumn{8}{|c|}{$\mathrm{mgL}^{-1}$} \\
\hline \multirow[t]{4}{*}{ 1-Bahr El-Baqar } & 2015 & 7.82 & 1.51 & 44.36 & 55.76 & 87.97 & 63.85 & 33.91 & 12.99 & 86.78 & 65.97 \\
\hline & 2016 & 7.95 & 1.52 & 44.99 & 55.99 & 88.96 & 65.41 & 35.68 & 13.96 & 87.95 & 65.88 \\
\hline & 2017 & 7.97 & 1.55 & 46.85 & 57.88 & 89.65 & 65.64 & 36.44 & 14.55 & 88.71 & 71.19 \\
\hline & 2018 & 8.00 & 1.69 & 47.45 & 58.98 & 90.56 & 65.70 & 36.64 & 14.69 & 89.72 & 73.22 \\
\hline \multirow[t]{4}{*}{ 2-Mahmodia canal } & 2015 & 7.8 & 0.75 & 0.18 & 0.01 & 0.01 & 0.005 & 0.016 & 0.075 & 0.002 & 0.020 \\
\hline & 2016 & 7.8 & 0.82 & 0.19 & 0.01 & 0.14 & 0.008 & 0.08 & 0.085 & 0.003 & 0.050 \\
\hline & 2017 & 7.9 & 0.93 & 0.25 & 0.14 & 0.16 & 0.009 & 0.08 & 0.095 & 0.006 & 0.080 \\
\hline & 2018 & 8.0 & 0.94 & 0.29 & 0.17 & 0.18 & 0.018 & $0 . .09$ & 0.099 & 0.008 & 0.090 \\
\hline 3-Damietta Nile & 2015 & 8.29 & 1.92 & 29.66 & 39.56 & 69.88 & 54.18 & 27.98 & 10.05 & 61.77 & 64.89 \\
\hline \multirow[t]{3}{*}{ Branch } & 2016 & 8.32 & 1.53 & 29.76 & 44.68 & 70.65 & 54.91 & 28.33 & 10.84 & 62.13 & 65.01 \\
\hline & 2017 & 8.39 & 1.96 & 30.88 & 45.12 & 71.69 & 54.30 & 28.64 & 11.02 & 62.79 & 65.21 \\
\hline & 2018 & 8.41 & 1.98 & 31.55 & 45.82 & 72.69 & 55.67 & 29.62 & 11.25 & 63.85 & 66.31 \\
\hline \multirow[t]{4}{*}{ 4-El Salam Canal } & 2015 & 7.35 & 0.32 & 4.76 & 1.15 & 1.64 & 0.75 & 0.98 & 0.76 & 0.99 & 1.06 \\
\hline & 2016 & 7.44 & 0.25 & 5.79 & 1.18 & 1.85 & 0.78 & 0.99 & 0.83 & 10.6 & 1.08 \\
\hline & 2017 & 7.45 & 0.28 & 5.81 & 1.87 & 2.09 & 0.83 & 1.01 & 0.84 & 1.08 & 1.21 \\
\hline & 2018 & 7.59 & 0.28 & 5.88 & 1.99 & 2.14 & 0.85 & 1.12 & 0.87 & 1.15 & 1.25 \\
\hline \multirow[t]{4}{*}{ 5-El-Gharbia Main } & 2015 & 7.1 & 0.41 & 2.33 & 0.35 & 0.11 & 0.012 & 0.02 & 0.17 & 0.31 & 0.47 \\
\hline & 2016 & 7.2 & 0.46 & 2.39 & 0.37 & 0.12 & 0.011 & 0.02 & 0.21 & 0.34 & 0.56 \\
\hline & 2017 & 7.3 & 0.50 & 3.42 & 0.37 & 0.12 & 0.011 & 0.03 & 0.29 & 0.36 & 0.61 \\
\hline & 2018 & 7.4 & 0.51 & 3.45 & 0.38 & 0.13 & 0.013 & 0.03 & 0.32 & 0.43 & 0.31 \\
\hline 6-Abu-Qir & 2015 & 7.54 & 0.71 & 90.22 & 28.11 & 23.54 & 19.20 & 9.87 & 0.05 & 10.25 & 19.83 \\
\hline \multirow[t]{3}{*}{ El-AAmia Drainge } & 2016 & 7.72 & 0.77 & 93.34 & 29.25 & 25.65 & 22.99 & 11.29 & 0.07 & 11.35 & 22.45 \\
\hline & 2017 & 7.81 & 0.86 & 104.15 & 35.65 & 26.57 & 23.44 & 12.15 & 0.09 & 12.46 & 23.69 \\
\hline & 2018 & 7.83 & 0.96 & 117.11 & 41.87 & 28.76 & 24.63 & 12.54 & 0.12 & 13.39 & 25.54 \\
\hline \multirow[t]{4}{*}{ 7- Rosetta Branch } & 2015 & 7.5 & 0.71 & 10.79 & 6.24 & 4.67 & 2.71 & 3.02 & 0.45 & 0.72 & 0.81 \\
\hline & 2016 & 7.6 & 0.72 & 10.88 & 6.55 & 4.86 & 2.79 & 3.15 & 0.66 & 0.76 & 0.83 \\
\hline & 2017 & 7.6 & 0.78 & 11.32 & 7.36 & 4.98 & 3.45 & 3.66 & 0.68 & 0.79 & 0.87 \\
\hline & 2018 & 7.7 & 0.79 & 12.77 & 7.92 & 5.11 & 3.66 & 3.74 & 0.79 & 0.81 & 0.92 \\
\hline \multirow[t]{4}{*}{ 8- El-Umoum } & 2015 & 8.5 & 4.33 & 43.98 & 34.27 & 7.10 & 7.54 & 9.32 & 0.29 & 0.84 & 0.87 \\
\hline & 2016 & 8.6 & 4.56 & 55.12 & 35.91 & 7.15 & 7.65 & 9.35 & 0.37 & 0.85 & 0.98 \\
\hline & 2017 & 8.7 & 4.81 & 55.61 & 35.99 & 7.22 & 7.99 & 9.36 & 0.38 & 0.90 & 0.99 \\
\hline & 2018 & 8.9 & 5.3 & 56.85 & 38.21 & 7.74 & 8.62 & 9.41 & 0.42 & 0.92 & 1.93 \\
\hline \multirow[t]{4}{*}{ 9-Ismailia Canal } & 2015 & 8.3 & 2.51 & 4.6 & 0.18 & 2.21 & 0.24 & 4.45 & 0.000 & 0.01 & 0.26 \\
\hline & 2016 & 8.4 & 2.82 & 4.6 & 0.18 & 2.26 & 0.25 & 4.50 & 0.000 & 0.02 & 0.27 \\
\hline & 2017 & 8.4 & 2.85 & 4.8 & 0.19 & 2.34 & 0.26 & 4.60 & 0.000 & 0.02 & 0.28 \\
\hline & 2018 & 8.5 & 3.03 & 5.2 & 0.22 & 2.42 & 0.29 & 5.10 & 0.010 & 0.03 & 0.28 \\
\hline \multirow[t]{4}{*}{ 10-El-Nobaria Canal } & 2015 & 7.20 & 0.85 & 5.029 & 0.62 & 1.53 & 0.42 & 0.065 & 0.012 & 0.019 & 0.019 \\
\hline & 2016 & 7.88 & 0.84 & 5.030 & 0.87 & 1.53 & 0.43 & 0.071 & 0.022 & 0.023 & 0.23 \\
\hline & 2017 & 7.88 & 0.92 & 60.32 & 0.87 & 2.58 & 0.52 & 0.081 & 0.036 & 0.014 & 0.41 \\
\hline & 2018 & 7.89 & 0.93 & 6.04 & 0.98 & 2.594 & 0.65 & 0.092 & 0.065 & 0.092 & 0.51 \\
\hline L.S.D at $5 \%$ level & ---- & ------ & ----- & 18.9 & 0.8 & 1.7 & 1.7 & 2.0 & 0.16 & 4.9 & 1.7 \\
\hline
\end{tabular}

*Mean samples were taken within 6 months of each year

$* \mathrm{EC} \mu \mathrm{s} / \mathrm{cm}=3000 \mathrm{FAO}$

*A-Law 48/1982; B-WHO (1993); C-BIS (2012); D-USEPA (2001); and E-Biernbaum (1995).

$*$ Mean \pm SD values of heavy metals in water samples $(n=4)$ of all canal that were collected the *Samples of drainage water were collected from twelve main canal of Nile Delta(Bahr El-Baqar, Mahmodia canal, Damietta Nile Branch, El Salam Canal, ElGharbia Main, Abu-Qir, In Rosetta Branch, , El-Umoum, El-Nasser Canal in Nubaria, Ismailia Canal) through four years of (2015, 2016, 2017, 2018 and compared to assigned reference values. 
There are concerns about the quality of this water, and the use of untreated or partially treated wastewater leads to pollution problems in surface and groundwater, leading to pollution of the soil and thus the most dangerous pollutants Are the heavy elements (AbdelFattah and Helmy 2015).

The most important pollutants in the Bahr El-Baqar are heavy metals such as lead, cadmium, cobalt, nickel and mercury, mainly industrial activities such as food industry, soap industry, paper industry, textiles, detergent industry and all waste received at Bahr ElBaqar. The prevalence of diseases is alarming (Park and Shin, 2006).

\section{2-Mahmodia canal}

Water quality is the main factor in its use, whether in drinking, domestic, industrial or agricultural irrigation. Therefore, monitoring the quality of water resources is very important. (Abdullah and Hussona, 2014) present study offered comprehensive water quality information of Mahmoudia canal. Cluster analysis grouped 10 sampling sites into three groups

\section{3-Damietta Nile Branch}

Damietta Nile Branch at Damietta Governorate has been suffered from intensive pollution. Damietta Nile Branch receives the water of a number of agricultural drains, which are heavily polluted by industrial and domestic sewage. The Damietta Branch receives polluted water of a number of agricultural drains, The Fertilizer Company is considered as the major point source of industrial pollution at Damietta branch. Many of villages on each banks of Damietta Nile branch without sanitation services, thus the river receive many wastewater resulted from industrial and domestic activities.

Damietta Governorate with area of about $910 \mathrm{~km} 2$ north of the Nile Delta and contains about 1.3 million persons living within its four administrative centers. These centers are Kafr Saad, Faraskour, El-Zarka and Damietta center. It was the Egyptian gate along the Mediterranean Sea before the construction of Alexandria about 300 years BC. The long of the Damietta Nile Branch in the Damietta Governorate about $40 \mathrm{~km}$ from Ras EL-Bar (north) to Sheremsah Village (south). The landuse/cover map of Damietta Governorate was showed in fig1. It consists of water, barren land, agriculture and urban. About 14 water samples were taken from the Damietta Nile Branch from Ras EL-Bar to Sheremsah Village (Table 2) to study the water quality in the Nile Water of Damietta Governorate (El-Gammal et al.,2014).

\section{4-El Salam Canal}

The Salam Canal is one of the most important irrigation projects being implemented in North Sinai. Some 500,000 feddans have been reclaimed on the eastern side of the Suez Canal through this project. The Salam Canal draws water from the Damietta Branch, one of the Nile River branches and two agricultural banks located east of the Nile Delta (Geriesh et al.,2015)

\section{5-El-Gharbia Main}

Mandour (2013) studied the main Western Bank and found many pollutants and this network goes through many neighborhoods in addition to increasing the values of heavy elements such as lead, cadmium, cobalt and nickel, and has received samples from many places, all exceeding the permissible limits, And the most dangerous is the increase of cadmium concentrations in drinking water as well as bacterial contamination.and exceed the recommended permissible limit.

\section{6-Abu-Qir}

The Gulf of Abu-Qir is located in Alexandria, Egypt. It is located between the mouth of Rashid and Abu Bakir branch. It is considered the world's most famous pollutant in the world. The pollutants are produced from dangerous black industries, especially those of nitrogen fertilizer factories that contain a high percentage of nitrate salts. Agricultural drainage, sewage and fertilizer companies, pesticides and paper companies.

The town of Abu-Qir is located in the southwest of Alexandria and has become a repellent for the population due to severe pollution, which took many lives after the disease was robbed all their possessions, after the Gulf of Abu-Qir and the front of the resort and tourists from all over the world as it had the environment of fishing, agriculture and tourism, Where $\mathrm{Abu}$ Abu-Qir is suffering from severe eutrophication and pollution from industrial and domestic waste. The food chain was eliminated in the Gulf due to the nomination of nitrates from Fertilizers company AbuQir to the Gulf

\section{7-In Rosetta Branch}

The Nile River basin is the dominant features of the northeastern basin quarter of the continents of Africa and extends $\sim 6825 \mathrm{~km}$. The Nile River divided into two branches; Rosetta and Damietta in the delta. Rosetta branch flows downstream Delta Barrage to the Northwest where it ends with Idina Barrage which releases excess water to the Mediterranean Sea (Abou El-Anwar and Samy1, 2018).

In Rosetta Branch of the River Nile, El Bouraie et al, (2010) detected pollution from of domestic, sewage, 
agricultural and industrial origin. Heavy metals $\mathrm{Fe}, \mathrm{Mn}$, $\mathrm{Zn}, \mathrm{Cu}, \mathrm{Pb}, \mathrm{Cd}, \mathrm{Co}$ and $\mathrm{Ni}$ were measured three times before, during and after winter period (low flow conditions) from August 2007 to April 2008, in surface river water. The study area contains significantly high concentrations of some potentially toxic metals such as $\mathrm{Fe}, \mathrm{Mn}, \mathrm{Zn}, \mathrm{Cu}, \mathrm{Pb}, \mathrm{Cd}, \mathrm{Co}$ and $\mathrm{Ni}$ which are derived from both natural and anthropogenic sources

\section{8- El-Umoum}

El Umoum drain is located in the west of Nile Delta and is considered one of the largest drains in this region. Geographically, the drain catchment area is located on latitude $35^{\circ} \mathrm{N}$ and longitude of $33^{\circ} \mathrm{E}$ (Figs. 1and 2). The atmospheric temperatures at the area vary from a minimum of $10^{\circ} \mathrm{Cat}$ winter season to a maximum of 30 $\mathrm{C}^{\circ}$ at summer season. The water temperature varies from 10 to $20^{\circ} \mathrm{C}$ in winter and from 28 to $30^{\circ} \mathrm{C}$ in summer. The drain catchment area covers approximately 1776 Km2 (422.860 Feddan) with a travel distance of about $41 \mathrm{~km}$. The drain conveys annual flow of about 2.50 billion $\mathrm{m} 3$ /year and is surged into the Mediterranean Sea through El Max pump station. The sources of water in the drain are the discharges of drainage water of $\mathrm{Abu}$ Hommos, Shrishra, Truga, El Deshoudy and El Haris drains. Some others drains, including Abis and El Qalaa drains are not included in the present investigation.

During the winter closure period (from January to February), the fresh water in the canals is subjected to strong un-steady-state flow conditions. However, a relatively high and stable flow pattern occurred during the period June-October. Also, during the winter closure period, the drains stop receiving excess water from irrigation which leads to accumulation of pollutants in the drain.

\section{9-Ismailia Canal}

Ismailia canal is a canal in Egypt, formerly known as the "Suez Canal Sweet"; starting from the Nile next to Shubra, north of Cairo, and reaching the Suez Canal at Ismailia, and then branch into two branches, one to Suez and the other to Port Said, From her mouth to "Nefeshah", and $89 \mathrm{~km}$ from Nefesh to Suez

Abdel-Sabour et al; (2001) reported that the studied area (Shoubra El-Khima, Bahteem and Mostorod) lies in the industrial area north of Greater Cairo.

This highest polluted come from collected from AlAhleya Plastic Company discharges the highest amounts of total Ni.

Delta steel company discharges the highest amounts of total $\mathrm{Fe}$ and $\mathrm{Mn}$, while Cairo Company for Fabric industry had the highest amounts of total $\mathrm{Cu}, \mathrm{Zn}, \mathrm{Co}, \mathrm{Pb}$ and $\mathrm{Cd}$.
Abu Zaabal fertilizer company, Egyptian alum company, Gas pipeline companies petro gas, Delta steel cables company Nile company for oil and detergents (Abdel-Sabour et al.,2001)

\section{0-El-Nobaria Canal}

The new Nubaria is an Egyptian city located in the north of Egypt, The lake is administratively located in the western part of the Nubaria canal on the northern parts of the Egyptian Western Desert in the part of the province of El-Beheira. The city of Nubaria was named after the Nubaria canal, which was named after its founder Nubar Pasha, In modern Egypt located directly on the Alexandria-Cairo desert road in the 80's, In Nubaria, there are a number of factories with different activities such as manure, packaging of agricultural crops and food processing. The water quality of ElNubaria Canal-the main surface water resource for the horizontal expansion projects in Western Delta showed in fig1.

El-Nubaria Canal is the major surface water source for the horizontal expansion projects in the West Delta Region. It is mainly fed by fresh water from El-Rayah El-Nassery and El-Rayah El-Beheiry. It serves a total area of 373,800 hectare (ha), (El-Gammal and Ali, 2008).

\section{Water pH}

Table 2 shows The $\mathrm{pH}$ of the water of most channels in Egypt ranges between (7.1-8.9) Which caused imbalance in the nutritional balance of living organisms due to toxic ions (FAO 2017).

\section{Salinity hazard}

Table 2 shows the ionic composition of water. Water of all drains in north Egypt was highly saline. The EC ranged from $(0.25-5.3) \mathrm{dS} / \mathrm{m}$ being of highly saline category. The highest EC was during the Annual of 2018, while the lowest EC was during the Annual of 2015.

\section{Heavy Metals}

Table 2 shows metals concentrations in water were varied between in all years fond, $\mathrm{Fe}(0.18-117.11), \mathrm{Mn}$ (0.01 -58.98), Zn (0.01 -90.56), Cu (0.005 -65.70), Pb (0.016 -36.64), Cd (0.000 -14.69), Co (0.002 -89.72) and $\mathrm{Ni}(0.019-73.22) \mathrm{mg} / \mathrm{l}$ respectively. that is predicted to become a serious environmental problem in the next few decades

\section{Legislative approaches in Egypt}

Laws related to water resources according to the Egyptian Laws 
Table 3. The limits of pollutants allowed in irrigation water

\begin{tabular}{lcl}
\hline parameters & FAO,2017 & Law $\mathbf{4 8}$ of $\mathbf{1 9 8 2}$ \\
\hline $\mathrm{PH}$ & $6.5-8.4$ & ---- \\
$\mathrm{EC}(\mathrm{dS} / \mathrm{m})$ & $<0.7$ & ---- \\
$\mathrm{Fe}(\mathrm{Iron})(\mathrm{mg} / \mathrm{l})$ & 5.0 & not more than 1 \\
$\mathrm{Mn}($ Manganese $)(\mathrm{mg} / \mathrm{l})$ & 0.2 & not more than 0.5 \\
$\mathrm{Zn}($ Zinc) $(\mathrm{mg} / \mathrm{l})$ & 2.0 & not more than 1 \\
$\mathrm{Cu}($ Copper $)(\mathrm{mg} / \mathrm{l})$ & 0.2 & not more than 1 \\
$\mathrm{~Pb}(\mathrm{Lead})(\mathrm{mg} / \mathrm{l})$ & 5.0 & not more than 0.005 \\
$\mathrm{Cd}($ Cadmium) $(\mathrm{mg} / \mathrm{l})$ & 0.01 & not more than 0.01 \\
$\mathrm{Co}($ Cobalt $)(\mathrm{mg} / \mathrm{l})$ & 0.05 & ---- \\
$\mathrm{Ni}($ Nickel $)(\mathrm{mg} / \mathrm{l})$ & 0.2 & ---- \\
\hline
\end{tabular}

Table 4. Water of canal's samples areas reported by several researchers

\begin{tabular}{cll}
\hline & Sites & The same result reached by: \\
\hline 1 & Bahr El-Baqar & (Abdel-Fattah and Helmy 2015) \\
2 & Mahmodia canal & (Abdullah1. Ali M.-m and Salah El-Dien Hussona ,2014) \\
3 & Damietta Nile Branch & (Ahmed et al.,2017) \\
4 & El Salam Canal & (Geriesh et al.,2015) \\
5 & El-Gharbia Main & (Mohamed et al.,2017) \\
6 & Abu-Qer & (Abdrabelnabi et al.,2017) \\
& El-AAmia Drainge & \\
7 & In Rosetta Branch & (Abou El-Anwar and Samy1, 2018) \\
8 & El-Umoum & (Elsokkary and Abukila, 2011) \\
9 & Ismailia Canal & (Goher et al.,2014) \\
10 & El-Nobaria Canal & (Agrama and El-Sayed 2013) \\
\hline
\end{tabular}

The most important laws and regulations concerning the protection of water resources from pollution in the Egyptian Law

-Law No. 93 of 1962 on the exchange of liquid wastes and its implementing regulations (Ministry of Housing, Utilities and Urban Communities

- Law No. 27 of 1978 concerning the regulation of public water supplies for drinking and use human consumption

- Law No. 48 of 1982 regarding the protection of the River Nile and waterways from pollution and its implementing regulations (no. 8) of 1983, as amended by its executive Resolution No. 402 of 2009

- Law 12 of 1984 on Irrigation and Drainage and its implementing regulations issued by Decree 14717 of 1987

- Law (4) for the year 1994 regarding protection of the environment as amended by Law No. 9 of 2009 and its implementing regulations

- Prime Minister's Decree No. 2318 of 2009, the establishment of the Supreme Council for the
Protection of the Nile River? Pollution of the Council of Ministers

\section{CONCLUSION}

The results of heavy elements in all sites of canals in North Egypt : Fe, Mn, Zn, Cu, Pb, Cd, Co and Ni (Table 2) indicate that a considerable number of the examined samples have higher contents than the maximum desirable standard for irrigation water that recommended by the FAO (2017) and the Egyptian Law 48 of 1982 .This could be attributed to the mixing of drain waters which constitute the higher concentration values.

Metals concentrations in water were varied between in all years fond, $\mathrm{Fe}(0.18-117.11)$, Mn (0.01 -58.98), $\mathrm{Zn}(0.01-90.56), \mathrm{Cu}(0.005-65.70), \mathrm{Pb}(0.016-36.64)$, Cd (0.000 -14.69), Co (0.002 -89.72) and Ni (0.01973.22) $\mathrm{mg} / \mathrm{l}$ respectively. Concentrations of heavy metals in water are compared with many guidelines to predict status of pollution (Guideline for water irrigation agricultural FAO, 2017 and Specifications of fresh water, according to Law 48 of 1982 ,Article 60 of the Regulations). water recorded values within the abnormal range. Results showed that all canals in this study are considered worst water for irrigation, very dangerous to 
human life and also all drains and mixed canals are considered above division of increasing salinity problems of irrigation water.

\section{RECOMMENDATIONS}

1- Effective implementation of laws and regulations.

2- Removal of encroachments and buildings on the canal's Borders and waterways, Nile River.

3- Raise awareness.

4- Provide the necessary resources to separate the waste of human activity from the biological and nonbiological systems (biotic and a biotic).

\section{REFERENCES}

Abdel-Fattah, M.K. and A.M. Helmy. 2015. Assessment of Water Quality of Wastewaters of Bahr El-Baqar, Bilbies and El-Qalyubia Drains in East Delta, Egypt for Irrigation Purposes

Abdelrazek, S.A.E. and R.I. M. Fayed. 2019. The Soil Management Practices and Land Use Periods in Relation to Soil Health of some Sandy Calcareous Soils in Egypt Alex. J. Soil and Water Sci. (Fac. Agric. Saba Basha). (1). No 3.

Abdelrazek, S.A.E. and I. Ragab. 2018. Effect of Wastewater and fertilizer application on calcareous soil and food crops in Borg El Arab - Egypt Monoufia J.Soil SCi. 3:257-266.

Abdelrazek, S. A. E, E.M.S. Ahmed, H.E.l. Mohamed, M. B. D. Waleed. 2016. Impact of Irrigation with Drainage Water on the Productivity of Forage Maize Grown on Calcareous Soil. Alexandria Science Exchange journal. 37:396-406.

Abdelrazek, S. A. E. 2017. Artesian water contamination with salinity and heavy metals at different distances at Borg El Arab, Alexandria - Egypt. Alexandria science exchange. 37 (3) :717-721.

Abdelrazek, S. A. E. 2014. Effect of wastewater irrigation onplant enzymes and soil health assessment in Borg Elarab Region. Ph.D. A thesis, University of SadatCityhttp://t1t.net/book/index.php?action=view\&id=2 070

Abdel-Sabour, M.F., F.H. Rabie, T. Mostafa and S.A. Hassan. 2001. Impact of industrial wastewater disposal on surface water bodies in Mostord area, north greater Cairo. J Environ Sci (China). 13(4):485-90.

Abdel-Shafy, H. I. and R. O. Aly. 2012. Water issue in Egypt: Resources, pollution andprotection endeavors. CEJOEM. 8(1): 3-21.

Abdrabelnabi, M.A. E.1., E. F. Abdelaty, A. E. Boder. 2017. Assessment of Heavy Metals Pollution of Some Water Resources (Kafr El-Dawar-Egypt) Natural Resources. 8: 306-319.

Abdullah, A.M, E.D. Hussona. 2014. Water Quality Assessment of Mahmoudia Canal in Northern West of Egypt. J Pollut Eff Cont 2: 121. doi: 10.4172/23754397.1000121
Abou El-Anwar, E.A., Y.M. Samy and S.A Salman. 2018. Heavy metals hazard in Rosetta Branch sediments, Egypt. J. Mater. Environ. Sci. 9 (7): 2142-2152.

Agrama, A.A. and E. A. El-Sayed .2013. Assessing and mapping water quality (case study: western delta -Egypt), International Water Technology Journal, IWTJ. 3(3).

Ahmed, M.A.M. and S. A. Medhat. 2017. Nile river sediment transport simulation (case study: damietta branch), Eleventh International Water Technology Conference, IWTC11 2007 Sharm El-Sheikh, Egypt. 423.

Ali, O. M., E. M. El-Sikhry and W. M. El-Farghal. 2013. Effect of prolonged use of Bahr ElBaqar drain water for irrigation on the total heavy metals content of South PortSaid soils. In: Proc. 1st Conf. Egypt. Hung. Env. Egypt. pp. 53-57.

Allam, G. 2007. International Water Resources Association, Water International; 32 (2): 205- 218. Water Resources in Egypt: Future Challenges.

APHA. 1971. American Publ. Health Assoc., American Water Works Assoc.-AWWA and Water Poll. Contr. Fed. WPCF, Standard Methods for the Examination of Water and Waste Water, 13th ed.

Drainage Research Institute .2000. Monitoring and Analysis of Drainage Water Quality Project, Drainage Water Status in the Nile Delta Yearbook. Technical Report No. 52: 9798.

DRI .2005. “Annual Drainage Water Quality Monitoring for the Year 2005". Egyptian Drainage Research Institute Handbook for.

Duncan, D. B. 1955. Multiple ranges and multiple F-tests. Biometrics. 11: 1-42

El Bouraie, M.M., A.A. El Barbary, M.M. Yehia and E.A. Motawea .2010. Heavy metal concentrations in surface river water and bed sediments at Nile Delta in Egypt. Suoseura - Finnish Peatland Society ISSN 0039-5471, Helsinki, 61(1): 1-12.

El-Gammal, M.I., R. R. Ali and R. Eissa. 2014. Land use assessment of barren areas in Damietta Governorate, Egypt using remote sensing. Egypt J Basic, Applied Sciences. I: 151-160.

El-Gammal, H. and H. Ali. 2008. Commissioning of Abandoned Drainage Water Reuse Systems in Egypt: A Case Study of Upgrading the Umoum Project, Nile Delta, Proc. 3rd Int. Conf. on Water Resources and Arid Environments and the 1 st Arab Water Forum.

Elsokkary, I. H. and A. F. Abukila. 2011. Water Quality Evaluation of El Umoum Drain, West Nile Delta of Egypt, During the Period 1989-2010 Alexandria Science Exchange Journal. 41( 7):134-152.

FAO .1985. Guidelines: Land evaluation for irrigated agriculture - FAO Soils Bulletin 55. Food and Agriculture Organization (FAO) of the United Nations, Rome, Italy.

FAO. 2017. User's manual for irrigation with treated wastewater. 
Fattah, M. K., S. A. E. Abdelrazek. 2014. The Improvement of the Quality of Irrigation Water Contaminated with Heavy Metals in the Borg El Arab, Egypt J. of Water Resource, Protect. 6:1703-171.

Geriesh, M. H. G., E. E. L. Ahmed, M. G. Ramadan, F. K. Mona, and A. M. Marwa. 2015. Geoenvironmental Impact Assessment of El-salam Canal on the Surrounding Soil and Groundwater Flow regime, north western Sinai, Egypt, carina, by the Egyptian Society For Environmental Sciences. 12 (1): 17-29.

Ghallab, M.H.M. 2000. Some physical and chemical changes on River Nile downstream of Delta Barrage at El-Rahawy drain. M. Sc. Thesis Fac. of Sci. Ain Shams Univ. Cairo, Egypt.

Goher, M. E., M. H. Ali, A. A.M. Ibrahim, H. F. Ayman, M. E.L. Seliem. 2014.Evaluation of surface water quality and heavy metal indices of Ismailia Canal, Nile River, Egypt, Egyptian Journal of Aquatic Research. 40: 225-233.

Hafez, S.H. 2004. Monitoring changes in water quality of some drains at the Northern Part of Delta to assess their suitability for irrigation. M. Se. Thesis, Fac. of Agric., Moshtohor, Zagazig Univ. Benha Branch, Egypt.
Hamed, Y.A. T. S., M.H. Abdelmoneim, M.A. H. ElKiki and R. Berndtsson. 2013. Assessment of Heavy Metals Pollution and Microbial Contamination in Water, Sediments and Fish of Lake Manzala, Egypt. Life Sci J. 10(1): 86-99.

Law. 48/1982. Periodical bulletin published by MAB National Committee in collaboration with the National Commission for UNESCO. 6th year, Nos 3,4. Dec. 1983. Cairo.

Mandour, R.A. 2013. Drinking Water Toxicity in Health and Diseases. Air Water Borne Diseases, 2:1. http://dx.doi.org/10.4172/2167- 7719.1000107

Mohamed, M., A. Elansary, M. Moussa. 2017. A modelling approach to manage water quality at gharbia main drain, Egypt Twentieth International Water Technology Conference, IWTC20 Hurghada. 18-20 May.

Park, J.H. and W.S. Shin. 2006. Immobilization of $\mathrm{Pb}$ contaminated soil using modified clay. Water Practice Technol. 1:1-10.

Soliman, E.M., A.M. EL-Saadani and S.A.E. Abdelrazek. 2006. Sustainable soil health as affected by cultivation periods and management practices in some new reclaimed soils A.R.E journal of environmental science Ain shams. 12 (4).

Tawfiq, M.E.F. 1998. Seasonal distribution of Cadmium in Lake Nasser. Aswan Reservior and River Nile at Aswan. Monoufia J. Agric Res. 32: 391-414. 


\section{الملخص العربي}

\section{رصد تلوث مياه الري في دلتا النيل في مصر بالمعادن الثقيلة}

سعد عبد الصمد السيد عبد الرازق

تعتبر جميع المصارف و القنوات المختلطة أعلى في الملوحة حيث تزداد عاما بعد عام في مياه الري.

وتعتبر المصارف الرئيسية ملحية بدرجة عالية ولا

تصلح للري ويصنف على أنها عالية الملوحة، وبالتالي لها تأثيرًا سيئًا على خصائص التربة و الإنتاجية ونظهر النتائج أن تركيز المعادن النقيلة ودرجة الحموضة و الملوحة مرتفعة بسبب تلوث جميع القنوات، ولا تزال أعلى من ودره الحدود الحرجة ولا يمكن استخدامها للري. ويوصى الباحث بالتتفيذ الفعال للقو انين و اللو ائح واز الة التعديات و المباني من على جسور الترع والمجاري المائية وجسور نهر النيل بجانب رفع الوعى، ونوفير الامكانيات اللازمة لفصل مخلفات النشاط البشى عن النظام البيئي الحيوي وغير الحيوي.

الكلمات المفتاحية: تلوث مياه الري، المعادن الثقيلة، التشريعات في مصر ، شمال مصر.
يدرس هذا البحث توزيع المعادن التقيلة في التزع و المصارف الواقعة في شمال مصر ولقد تم تحديد ثمانية معادن(الحديد، المنجنيز، الزنلك، النحاس، الرصاص، الكادميوم، الكوبلت، النيكل) في الماء. وتفاوت تركيزات المعادن في الماء بين جميع السنوات فكان الحديد (1 ا, . (1) .

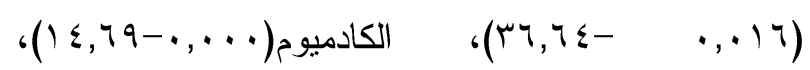

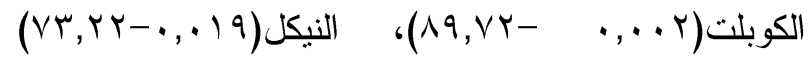
ملجم/لتز على التوالي. تم مقارنة تركيزات المعادن التقيلة في المياه مع العديد من المعايير للتنبؤ بحالة التلوث (المعيار العالمي لمياه الري الزراعي، عن منظمة الأغذية

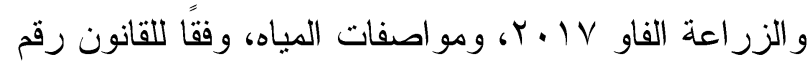

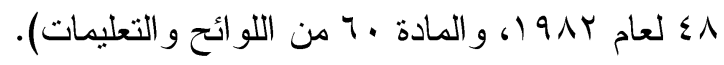
أظهرت النتائج أن جميع القتوات في هذه الدر اسة تعتبر أسوأ مياه للرب، وخطيرة جدًا على حياة الإنسان وأيضًا 